\title{
Kernos
}

Revue internationale et pluridisciplinaire de religion grecque antique

15 | 2002

Varia

\section{Dario M. cosI, L'arkteia di Brauron e i culti} femminili

\section{Gunnel Ekroth}

Édition électronique
URL : http://journals.openedition.org/kernos/1426

DOI : 10.4000/kernos. 1426

ISSN : 2034-7871

\section{Éditeur}

Centre international d'étude de la religion grecque antique

Édition imprimée

Date de publication : 1 janvier 2002

ISSN : 0776-3824

\section{Référence électronique}

Gunnel Ekroth, «Dario M. cosı, L'arkteia di Brauron e i culti femminili », Kernos [En ligne], 15 | 2002, mis en ligne le 16 juin 2011, consulté le 24 septembre 2020. URL : http://journals.openedition.org/kernos/ 1426 ; DOI : https://doi.org/10.4000/kernos.1426 
Dario M. Cosi, L'arkteia di Brauron e $i$ culti femminili. Materiali della giornata di approfondimento organizzata dal Seminario avanzato sul tema $I l$ politeismo promosso dall'insegnamento di Storia delle religioni del mondo classico ( 5 luglio 2000), Università degli studi di Bologna, Facoltà di lettere e filosofia, Dipartimento di storia antica, 2001. 1 vol. $21 \times 29 \mathrm{~cm}, 95$ p., 13 pl.

This book originates in a one-day seminar organized by the department of ancient history at the University of Bologna in July 2000, dedicated to the study of the arkteia at Brauron and female cults. The book can be categorized as an overview and summary of recent research dealing with these topics. After a brief introduction by Dario M. Cosi, the book's editor, there follow five contributions.

The first one, by Diana Guarisco, constitutes a review of the source material available for the study of Brauron and the arkteia, as well as some of the research dealing with the site and the cult. She briefly presents the literary sources, including the scholia and the lexicographers, the inscriptions, the archaeological evidence from the site itself, as well as the tich votive material, such as sculpture, reliefs and the krateriskoi connected with the arkteia. In her review of the modern scholarship she singles out certain trends, for example, work dealing with rituals and with initiation in particular, linguistic issues and the iconography of the krateriskoi. More than a third of the chapter is taken up by a detailed account of Mario Giuman's recent study of Brauron, $L a$ dea, la vergine, il sangue. Arcbeologia di un culto femminile (1999) and one finally longs actually to read this book rather than just reading about it.

The second contribution by the same author, which attempts to contextualize the ritual at Brauron by comparing it with the other important sanctuaries of Artemis in Attica and elsewhere, apparently also draws a lot on Giuman's study. Of particular importance for the understanding of Brauron are the sanctuaries at Halai and Mounychia which demonstrate a number of traits similar to the former sanctuary, for example the performance of initiation rituals, the presence of krateriskoi and similar topographical lay-outs. Looking outside the Athenian territory, there are three cultic environments which can also be compared with Brauron on a typological and functional level: the cults of Artemis at Kyrene, in Thessaly and at Sparta.

Directly pertaining to the site of Brauron is also the last paper of the volume, in which Rita Venturi offers some observations on the archaeological situation at Brauron in June 2000. The text is based on 13 colour plates found in the back of the book. She describes the topographical lay-out of the site and the various architectural remains, as well as comments on the actual state of the sanctuary today and how the modern environment affects the impression the visitor gets, the latter a most welcome perspective. She emphasizes the importance of water at the sanctuary, most of all the spring at the foot of the rock on which the temple was constructed, but also the river Erasinos. Unfortunately the numbers of the actual plates and the numbers given in the text have been mixed up. The text accompanying pl. I (p. 90-91) actually concerns pl. II, while the text to pl. II and III (p. 91-92) concerns pls. III, IV and V, the text to pl. IV (p. 92-93) addresses pl. VI, and so forth. There are also some unattractive spelling mistakes (p. 92, n. 8: Kintis instead of Kondis, and n. 9: Brauros instead of Brauronos)

The book also contains an account by Alessandro Alberti of an interdisciplinary seminar in Urbino in May 2000, dealing with the bears of Brauron. A number of prominent scholars attended, addressing a variety of highly interesting topics. To mention a few, W. Burkert discussed the terminological distinctions between ritual categories such as mysteries, initiation and rites of passage, and 
their relation to the rituals performed at Brauron, while Petros Themelis focused on the topography of the sanctuary in the light of a 3 rd-century- $\mathrm{BC}$ inscription found at Brauron, which mentions a number of buildings. Mario Guiman explored the krokotos, the signification of the colour of this piece of clothing in antiquity and the plant from which the colouring was derived, the crocus. Dina Peppas-Delmousou commented on the sacred money of Apollon mentioned in a stele from 416/15 BC found at Brauron and the presence of a strong male aspect at the sanctuary, illustrated by a 4th-century dedication by some stratiotai on behalf of their commander, perhaps after having completed their military service. The seminar at Urbino clearly must have been a very interesting event but one would have wished for some information on where the contributions of the wellknown participants will be published in full.

More related to the sphere of feminine cults in general rather than to Brauron is the contribution by Saviero Gualerzi, dealing with a number of questions concerning Sappho and her female thiasos on Lesbos. The author provides a sort of Stand der Forscbung on Sappho and her contemporary environment and discusses how participation in this tbiasos may have functioned as a preparation for the future marriages of the young women, in particular pertaining to the emotional aspects, but also physical beauty and sexuality. Of central interest is also the role of homosexual love within Sappho's group, a matter on which scholars' opinions are divided. Wilamowitz, for example, claimed that the thiasos was only a religious group concerned with the cult of Aphrodite and the poetry of Sappho, an interpretation which Gualerzi finds to be lacking in imagination and neatly remarks upon as la visione poco elastica dell'autore tedesco (p. 49).

On the whole, this is more a book about scholarship than actual research focusing on Brauron and female cults. For whom this work is conceived is not entirely clear but it is best seen as an introduction to the sources and research concerning Brauron in particular and female cults in general. One dominating aspect is the review of scholarship. Here, however, one feels a certain tendency of bias towards Italian and French research at the cost of the general picture and this is far from constituting an attempt at an overall bibliography. There is, for example, no reference to Ken Dowden's Death and the maiden, a study which is just as important for Brauron as Pierre Brulé's La fille d'Athènes. The book could function as an introduction to the whole Brauron complex for students but if this was one of the intentions, it might have been achieved in a more comprehensive manner.

Gunnel Ekroth

(Stockholm University)

Susan Deacy, Alexandra Villing (éds), Athena in the Classical World, Leiden, Brill, 2001. 1 vol. $16 \times 24,5 \mathrm{~cm}$, xII +435 p., 24 pl. ISBN : 90-0412-142-0.

Ce volume rassemble une vingtaine de communications faites lors du colloque sur Athéna organisé au Lindon College d'Oxford en avril 1998. Les auteurs ambitionnent à la fois de combler un vide dans les études de religion grecque, dont aucune n'a été récemment consacrée à la déesse ( $c f$. l'état de la question fourni par les éditrices en introduction), et de proposer une approche interdisciplinaire du sujet. Les articles sont répartis en trois catégories, quelque peu artificielles car elles se recoupent continuellement : le culte, le rituel et le mythe; les représentations artistiques; les traitements littéraires. On obtient ainsi un livre extrêmement riche et diversifié, dont le titre ne recouvre cependant pas exactement le contenu, puisque la Grèce occupe une place écrasante dans ce "monde classique ", tandis que l'Italie ne suscite que deux articles (Athéna dans l'Énéide 